Pragmatist Legacies in Aesthetics

\title{
Introduction to Pragmatist Legacies in Aesthetics
}

\section{Roberta Dreon}

\section{OpenEdition}

\section{Journals}

Electronic version

URL: http://journals.openedition.org/ejpap/2259

DOI: 10.4000/ejpap.2259

ISSN: 2036-4091

\section{Publisher}

Associazione Pragma

Electronic reference

Roberta Dreon, "Introduction to Pragmatist Legacies in Aesthetics", European Journal of Pragmatism and American Philosophy [Online], XIII-1 | 2021, Online since 02 April 2021, connection on 04 April 2021. URL: http://journals.openedition.org/ejpap/2259 ; DOI: https://doi.org/10.4000/ejpap.2259

This text was automatically generated on 4 April 2021.

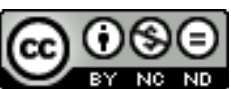

Author retains copyright and grants the European Journal of Pragmatism and American Philosophy right of first publication with the work simultaneously licensed under a Creative Commons Attribution-

NonCommercial-NoDerivatives 4.0 International License. 


\title{
Introduction to Pragmatist Legacies in Aesthetics
}

\author{
Roberta Dreon
}

\section{Introduction}

1 Is there anything like a pragmatist tradition in aesthetics, representing a third option beyond analytic aesthetics and the broad, multifaceted galaxy of continental aesthetics? A comparative analysis seems to be problematic, not least because of the variety of continental aesthetics, which is so broad as to include classic German aesthetics and phenomenological theories of aesthetic experience, critical views such as Adorno's negative aesthetics and Foucault's aesthetics of self-cultivation and creation, to mention just a few names and lines of inquiry belonging to this field.

2 The present issue of the European Journal of Pragmatism and American Philosophy has been designed as an investigation into the diverse ways of doing aesthetics in the wake of Pragmatism.

3 Even though the term "pragmatist aesthetics" first became widespread through Richard Shusterman's seminal work in the '90s (Shusterman 1992), it is used here to bring together a vast array of approaches that have been independently evolving within the aesthetic field with more or less explicit references to Pragmatism (mainly Dewey's aesthetics), such as everyday aesthetics, environmental aesthetics, social aesthetics, and somaesthetics. It also includes the work of some important philosophers - e.g. Richard Rorty, and Joseph Margolis - who have been influenced by pragmatist approaches and categories, while taking part in the analytical debate in aesthetics. Furthermore, one should recognize that pragmatist options are still very much available among emerging trends in aesthetics - cf. Mark Johnson's work on the aesthetic in experience (Johnson 2007), Alva Noë's conception of artworks as "strange tools" (Noë 2015) and, more recently, Shaun Gallagher's inquiries into artistic performance (Gallagher forthcoming). 
4 Evidently, this cannot be a plea in favour of clear-cut, top-down classifications. Rather, it is a suggestion grounded in the need to take account of a cluster of already wellestablished research trends and promising new lines of investigation that do not match any of the usual categories by which we functionally orient ourselves in the huge field of aesthetics. In the spirit of Pragmatism, these categorizations will be dealt with as provisional and operative - as being as approximate as they are useful. As James puts it in Pragmatism (James 1975), we tend to be both conservative and innovative in our knowledge of the world, for we tend to select new ideas and theories that, while fitting new phenomena, have grown out of previous habits of thought and classification. Hence, one first strategy for briefly characterizing a family of aesthetic approaches as pragmatist is to compare them with the other two main Western traditions and approaches.

5 One first goal of the present issue, then, is to map and highlight the diverse heritage of Pragmatism in aesthetics. Somaesthetics, environmental aesthetics, everyday aesthetics, social aesthetics are some of the many ways to do aesthetics in the wake of pragmatism. Some authors have developed pragmatist insights without coining any new labels for their views, as is the case with Joseph Margolis' anthropology of the arts and philosophy of culture (Margolis 2009 and Margolis 2015), Mark Johnson's theory of the aesthetic in experience (Johnson 2007), and Jean-Pierre Cometti's focus on artistic practices, features, and norms (Cometti 2012). One could sum up such a complex panorama by stating that pluralism remains the hallmark of pragmatism even in the aesthetic field.

6 A second, connected aim is to further highlight the fact that English-speaking aesthetics is a much larger field than analytic aesthetics, and that philosophical aesthetics has been conceived - and is still thought - of as broader than the philosophy of art. The two sides of this claim are intertwined, insofar as analytic aesthetics has been doubtless understood as philosophy of art, by simply putting aside the complicated history of the birth of the discipline in the 18th century. Even when authors sharing a pragmatist approach reflect on the arts, they tend to consider them as artistic practices, an integral part of human experience, and behaviours that are structurally intertwined with ethical, political, and cognitive issues and transactions, rather than as specific entities and events belonging to an independent artworld. Consequently, pragmatist responses to classic analytic questions like the definition of "Art," or the ontological status of artistic entities, can sound vague to analytic minds and not because they lack analytical capacities. Instead, the point is that pragmatist approaches usually reject the autonomist framework that is generally assumed as a tacit presupposition by most analytic philosophy of art.

7 A comparison with continental aesthetics is much more complex because of the extremely varied forms this heterogeneous field takes, as mentioned above. One first general point might be that the successors of Dewey, James, and Peirce in aesthetics generally reject formalistic approaches to the arts, as well as any conception of art for art's sake. On the other hand, pragmatist aesthetics converges with classical German aesthetics insofar as it did not begin univocally as a philosophy of art, but displayed a close connection with perception and its cognitive value already with the founding fathers of the discipline. One might even say that from the very beginning aesthetics was conceived of as part of a theory of experience; consequently, one could point to the continuity between Baumgarten's idea of aesthetics as cognitio sensitiva (sensitive 
cognition) and pragmatist developments in aesthetics. However, this convergence conceals a deep difference, because the Germans tended to consider sensitive perception an eminently cognitive resource, while Dewey radically reinterpreted experience and cognition itself against the background of living organisms' transactions with their environment. Furthermore, a crucial difference is represented by the pragmatist distance from the standard opposition between subject and object implicitly underpinning most continental conceptions of experience, as rightly noted by Giovanni Matteucci (Matteucci 2019). Human organisms' embeddedness in their environment - their being constituted through and through by their continuous interactions with a world of which they are an active part - is a clear marker of pragmatist approaches to experience, although this idea may be formulated in stronger or weaker forms, depending on the scholar. A further correlated and distinctive feature is a non-reductive naturalistic stance, which marks off pragmatist aesthetic approaches even from those continental aesthetics sharing a strongly relational attitude - such as Heidegger and Merleau-Ponty's theory of human existence as being-in-the-world.

Finally, a few words should be added about the very formula "pragmatist aesthetics" or "pragmatic aesthetics" with reference to Dewey's avoidance of such terms in his major work on the topic. This circumstance could represent a crucial objection to the current proposal, namely to adopt this expression in order to bring together a family of approaches in aesthetics, given that Dewey did not use such terms despite being the only classical pragmatist to devote a whole volume to the issue of the aesthetic in experience (notwithstanding the fact that some important aesthetic insights are also to be found in both Peirce's and James's philosophy). ${ }^{1}$ I agree with Richard Shusterman that probably one of the main reasons why Dewey refrained from labelling his proposal as "pragmatist" or "pragmatic" aesthetics was defensive: he was acting in response to the frequent criticism levelled against his philosophy - such as accusations of it being too utilitarian, instrumental, or even supportive of the American capitalistic economy (Shusterman 2014: 17). For sure, the controversies with Croce, who accused Dewey of plagiarism, and Pepper, who accused him of promoting a still idealistic and not yet sufficiently pragmatist aesthetics, further complicated the situation, in which Dewey evidently felt uneasy (see Alexander 1987: 2).

9 Nonetheless, Dewey undoubtedly conceived of his aesthetics as having a deep pragmatist meaning when focusing on the consequences of his ideas. He stated:

a philosophy of art is sterile unless it makes us aware of the function of art in relation to other modes of experience, and unless it indicates why this function is so inadequately realized, and unless it suggests the conditions under which the office would be successfully performed. (Dewey 1989: 17)

10 Far from being a mere theoretical proposal, his idea of the aesthetic as something inherent in the basic structure of experience is always strongly linked to the (broadly speaking) political aspect of human experience. Dewey's naturalistic aesthetics was closely connected to the idea of fostering opportunities to develop a good, satisfying human life for both individuals and groups, whatever this might mean in each specific context (Mead 1926, Cometti 2012). His aesthetic programme was strictly tied to his conception of democracy as a way of life, as originally stated by Robert Westbrook (Westbrook 1991) and now extensively defined in the previous issue of this journal, edited by Ana Honnacker and Magnus Schlette (European Journal of Pragmatism and American Philosophy, 2020/2, XII). 
11 In what follows, I will use the term "pragmatist aesthetics" in the plural and in a broad sense, to refer to the varied range of trends, authors, and philosophies that have more or less direct connections with the Pragmatist tradition of thought - particularly Dewey's aesthetics - insofar as this tradition represents either their original background or a conscious source of inspiration for them. I will suggest a first tentative mapping of the field (\$.2), by also including some references to papers collected in this issue. The third and last section (\$.3) will provide an exploration of the main "family resemblances" between movements and scholars belonging to the area of pragmatist aesthetics.

\section{Mapping the Field}

12 Although I wish to be as comprehensive as possible, the picture I will be offering is far from exhaustive and remains open to integration. Given this caveat, I believe one must begin with Richard Shusterman, whose contribution to revitalizing the pragmatist interest in aesthetics cannot be overestimated. The consequences of his cultural operation in the aesthetic field could probably be compared to the impact of Richard Rorty and Hilary Putnam's capacity to bring the pragmatist tradition to the foreground of the philosophical debate, after years of marginalization. ${ }^{2}$ This was particularly the case in France, as stated by Jean-Pierre Cometti, who was one of the supporters of this change within the aesthetic debate (Cometti forthcoming). The French edition of Shusterman's Pragmatist Aesthetics in 1992 provided a decisive contribution to the longawaited publication of the French translation of Dewey's Art as Experience, which however was only to appear in 2010. Shusterman refreshed the aesthetic debate in the Nineties by problematizing the boundaries between Fine and Popular Arts, as well as by arguing for a limitation of the role of interpretation within aesthetic experience. Shusterman further highlighted the broadly political implications of an aesthetic education inspired by Dewey as capable of criticizing current conditions and showing melioristic potential - a feasible (and pleasant) alternative to both Adorno's negative aesthetics (Adorno \& Horkheimer 1947/2002: 113) and Bourdieu's criticism of the implicitly interested character of aesthetic disinterest (Bourdieu 1983). What also attracted considerable attention was Shusterman's development of pragmatist aesthetics as somaesthetics, which is to say his expanded conception of aesthetics as the cultivation of bodily consciousness. In this issue, an interview with Richard Shusterman himself sheds light on his approach in its various phases, by reconstructing some historical circumstances and providing answers to some questions and arguments against possible objections. The current issue of the journal also features a proposal by Mark Tschaepe in line with the somaesthetic project. Tschaepe suggests taking Peirce's discourse on the irritation of doubt as originating the process of inquiry in a literal sense as bodily discomfort and almost pain. Significantly, he shows that aesthetic experience also includes negative feelings that can be momentous in engendering the somatically grounded forms of awareness, as well as of moral imagination and empathy, by which a person actually faces a problematic situation.

13 Alongside Shusterman's proposals, mention must be made of both so-called environmental and everyday aesthetics. Environmental aesthetics is not simply focused on a renewed interest in natural beauty, even if this has been an important point within the analytical debate on extending the field of aesthetics beyond the philosophy 
of art and the artworld. The key figure here is certainly Arnold Berleant, whose The Aesthetics of Environment appeared in 1992, the same year as Pragmatist Aesthetics. Although Dewey is not frequently mentioned in that book, his influence is clear from the very beginning and explains much of the difference between Berleant's engaged environmental aesthetics and Allen Carlson's cognitively oriented position (Carlson 2009), as well as Berleant's distance from the Kantian stance adopted by Emily Brady (Brady 2003). At least two pivotal tenets of his philosophy are distinctively Deweyan and pragmatist. Firstly, his reconceptualization of the environment and its relationships with humans as something which escapes the subject-object dualism and the dialectic of domination characterizing the aesthetic tradition from Kant to Adorno. The environment is not the outside world, which can become either an object of distanced contemplation or nature awaiting to be subdued by reason. Rather, it is a complex web of interactions, including cultural and social features along with natural and non-human aspects. Human organisms are an integral part of the environment, they are constituted through and through by their interactions with it and, at the same time, they constantly contribute to dynamically building and changing the environment from the inside. In a formula, radical embeddedness and engagement take the place of the subjective representation of an external object and of disinterested contemplation. Secondly, Berleant adopts the pragmatist attitude when affirming that "all aesthetics is, in some sense applied" (Berleant 1992: xii), because it has practical consequences and makes a difference in human lives. His final proposal of further developing environmental aesthetics towards a form of social aesthetics strengthens this research trend (Berleant 1992). This point is connected to a further Deweyan claim that will prove central to everyday aesthetics, namely the idea that aesthetics applies "to matters of daily life, to activities and objects that serve some practical purpose" (Berleant 1992: xii). In this sense, an ecologically oriented aesthetics favours new convergences between aesthetics and ethical issues and supports the claim against a compartmental view of the two fields. Thomas Alexander - to whom we owe the first and most extensive book on Dewey's aesthetics - develops an eco-ontology and aesthetics of existence that seem to go in an at least partially convergent direction, contributing to the field with a clear metaphysical radicalization (Alexander 2013:17). In the face of the dramatic deterioration of environmental conditions, possible developments and pragmatic commitments could and should be favoured at the intersection between aesthetic and ethical concerns.

The tendency to enlarge the field of aesthetics far beyond the arts becomes a hallmark of so-called everyday aesthetics. Dewey's conception of the aesthetics as part of a theory of experience plays a fundamental role, along with his criticism of the museum conception of art and his continuity thesis, according to which eminently artistic practices enhance aspects and features belonging to ordinary experience. Everyday aesthetics gives strong emphasis to the concept of "having an experience," demonstrating that "aesthetic experience is possible in every aspect of people's daily life, ranging from eating a meal or solving a math problem to having a job interview," as stated by Yuriko Saito (Saito 2021). A particularly lively debate concerns the ways of interpreting the connections between the ordinary and the extraordinary in the course of experience. In this issue, Thomas Leddy offers an interesting contribution to solving such problem through an explicit reference to Dewey's anti-dualistic stance. Making something special or extraordinary within the flux of experience requires neither a distinctive kind of perception - an allegedly aesthetic perception, i.e. a contemplative, 
as opposed to practical, and/or cognitively informed perception - nor a normative attitude opposed to an allegedly merely descriptive stance. Leddy argues that from a Deweyan point of view there are no sharp boundaries between the practical and the disinterested, the descriptive and the honorific, as well as between the cognitive and the qualitatively rich background of experience. Rather, making something extraordinary and framing it within the background of experience has to do with variations of intensity within the continuum of experience.

15 All of these trends - somaesthetics, environmental aesthetics, and everyday aesthetics - have important implications with regard to human actions in the socio-political space. However, it must be noted that social aesthetics already represented a native trend within American philosophy, stemming from John Dewey, Thorstein Veblen, and C. Wright Mills, as originally stated by Rick Tilman (Tilman 2004). From this perspective, aesthetic theory has the role of promoting the reconstruction of (post)industrial societies in view of shared goods that could be communally enjoyed, given the strongly social interdependence and pervasive aesthetic needs of human beings. Of course, the applicability of this kind of approach to current societies and economic systems must be evaluated and tested. In the current issue of the journal, Trygve Throntveit reconstructs Veblen's aesthetic theory by emphasizing similarities with Dewey's position. Veblen's merit does not lie solely in his criticism of allegedly pure aesthetic taste: many decades before Pierre Bourdieu (Bourdieu 1979), he called the Kantian paradigm of disinterestedness into question by focusing on its deeply social implications. Throntveit claims that Veblen even suggested a positive aesthetic theory that appears to share many similarities with Dewey's conception of democracy as involving a participatory and more inclusive form of life, as well as a qualitatively richer and more fulfilling existence. Veblen's aesthetic theory entails an idea of the aesthetic which refers to the fullness of the life of the individual within the group he or she belongs to - a hypothesis that is based on his belief in the evolutionary value of basic human sociality. In his view, democratic renewal must and should be shaped through public work, reorienting the so-called instinct of workmanship towards prosocial purposes.

Further promising lines of research in the field of pragmatist aesthetics are represented by the more or less explicit revival of Deweyan insights developed at the intersection with radical embodied and enactive ideas of the mind, and by a nonreductive approach to neurological components in the experience of the arts. Mark Johnson's long-standing research on the bodily roots of meaning finds a decisive complement in Dewey's focus on the qualitative and affective, i.e. aesthetic, features of experience. In his view, pragmatism combines phenomenology, linguistics, affective neuroscience, and enactivism by constructing an aesthetics of human understanding, namely a fully embodied interpretation of human thought and language. Our capacity to handle meanings and symbols seems to be rooted in the aesthetic dimensions of embodied action, in "qualities, images, patterns of sensorimotor processes, and emotions" (Johnson 2007: 1). Further convergences (and divergences) between pragmatist aesthetics and recent developments within enactivism (especially Noë 2015 and Gallagher forthcoming) would deserve further investigation. In this journal, Giovanni Matteucci provides an interesting contribution at the crossroads between Johnson's approach to the aesthetic dimension of meaning and Shaun Gallagher's reinterpretation of the extended mind hypothesis, which definitely goes beyond Andy Clark's functionalism and is explicitly inspired by Dewey. Matteucci claims that a 
theory of meaning involving basically aesthetic features should emancipate itself from any residue of the subject-object opposition. His targets are both the idea of meaning understood as something arising from bodily actions reacting to external stimulus and the idea of the mind externalizing some of its functions in objects and tools. Conversely, Matteucci argues, Gallagher's understanding of the extended mind as situated within organism-environment interactions implies a major emphasis on the aesthetic quality of each organism's experience, on account of its being essentially embedded in the environment and perceiving it from the inside.

17 Jay Schulkin's paper offers a contribution to a cultural-naturalistic - i.e. non-reductive - view of music by situating "cephalic capabilities" within human experience both synchronically and diachronically, i.e. from the point of view of our evolutionary history. Musical sensibility and music production appear to be pervasive in human experience because they contribute in different ways to adapting our cephalic organization to changing circumstances and, more generally, to improving human life development and enhancement.

18 A few final words must be added about the original path covered by Joseph Margolis, who went from being one of the key figures in the debate on the analytic philosophy of art to supporting the philosophy of culture as a more adequate background for considering human artistic practices. This transition should not be regarded as a break, but rather as a radical consequence of the very categories he introduced within the analytical debate (Dreon 2019). From the very beginning, his idea of the cultural emergence of works of art from a specific form of life (Margolis 1974) was alien to Danto's conception of the artworld as the independent space of the necessary and sufficient conditions for something to be a work of art (Danto 1964 and Danto 1992). Consequently, he found a fruitful convergence with the pragmatist tradition - with cultural naturalism on the one hand and with a basic distance from any autonomist pretension about art on the other. In this issue, Margolis presents a paper in his distinctive polemical vein, in which he strongly criticizes any compartmentalization of aesthetics and the arts based on broadly Darwinian considerations about the emergence of human thought out of already intelligent animal behaviours. His adherence to "lax" pragmatism against Kant's claims concerning transcendental reasoning goes beyond philological correctness and represents a way to come to terms with the autonomist illusion.

19 To conclude this tentative mapping, I must express my regret for the lack of contributions on Peirce and James' aesthetic legacy in the present issue. Rocco Monti's paper is a partial exception insofar as it reassesses the connections between Peirce's conception of vagueness - along with Dewey's theory of quality - and Eco's notion of "open work." Mark Tschaepe - as already mentioned - also develops an inquiry that begins with a reference to Peirce's conception of doubt as irritation.

20 Although Dewey was the only classical pragmatist to write extensively about aesthetics, both Peirce's and James' works offer important insights which have already been explored by scholars and experts on these authors, as the literature shows. ${ }^{3}$ The lack of papers about their influence on aesthetics in this issue should be considered merely contingent and as a stimulus to further explore and develop the variety of ways of practising aesthetics in the light of Pragmatism. Hence, the current tentative sketch certainly remains open to integration. ${ }^{4}$ 


\section{Family Resemblances}

21 The field just outlined is quite varied. There is no single feature that can be ascribed to every trend and exponent of this field, as is invariably the case when dealing with broad classifications. Nonetheless, one can detect a number of family resemblances between parents and children, nieces and aunts, metaphorically speaking. Even "acquired relatives" seem to share certain modes of behaviour, habits and gestures, as is frequently the case with long-standing couples.

From this perspective, I suggest identifying a series of more or less common features characterizing the field as pragmatist or influenced by pragmatist authors, primarily Dewey.

One first aspect (1) is the common assumption that aesthetics is much broader than the traditional philosophy of art, gravitating around the fine arts or high culture objects and performances, which are considered the prototypical aesthetic entities. This claim can be stated in the form of an extension of the range of objects and events to be investigated. Pragmatist aesthetics ultimately includes popular arts, mass culture, and alternative artistic genres, as in the famous case of Richard Shusterman's brilliant essay on The Fine Art of Rap (Shusterman 1992) - a genre which proves to be as refined in its early manifestations as the poetry of T.S. Eliot, and no less socially exclusive (as Pierre Bourdieu could have noted). Resistance against the tendency to conflate aesthetics with the philosophy of art manifests more radically in the claim that the aesthetic is widespread in everyday objects and practices and should be cultivated within ordinary experience, as it occurs in everyday aesthetics. Aesthetics can be reframed as involving a theory of experience, as is the case with Dewey, Berleant, and Alexander, but also with Matteucci in this issue, and with authors who have a strongly embodied background, such as Mark Johnson. The conception of aesthetics as the prevalent theory of experience in the pragmatist field is not primarily cognitively oriented, as was instead the case in the early days of this discipline with Baumgarten and Kant's first Critique. Rather, Dewey's approach to experience is anchored in the ontological claim that human organisms are part of the environment and constitutively interact with its various aspects - natural as well as social and cultural ones - from the inside. Finally, the movement beyond the idea of aesthetics as the philosophy of art also takes the form of Joseph Margolis' mature dissatisfaction with allegedly strict disciplinary boundaries. In his view, in order to understand artistic practices and products, a philosophy of culture and a philosophical anthropology are required, which is to say a picture of what it means to be and to have become human through the acquisition of a shared culture and language, common norms, societal and meaningful practices, from both an ontogenetic and a phylogenetic point of view (Margolis 2017).

Complementary to this is Dewey's opposition to the view of art as an independent realm or an autonomous system ruled by its own principles and excluding any heteronomy. This second claim (2) characterizing part of pragmatist aesthetics can be summed up as an anti-autonomistic stance: it is significantly more visible in authors who engage with the analytical debate on the definition of art and distance themselves from the very presupposition of a self-sufficient artworld, seen as standing on its own both ontologically and normatively. This stance is stronger in the cases of Joe Margolis and Jean-Pierre Cometti, whose book Art et facteurs d'art (Cometti 2012) would deserve closer scrutiny from a pragmatist point of view. Here, Cometti criticized the debate on 
the ontology of art as a kind of "fascination" insofar it was (and still is) guided by the pretension that artistic entities are out there and can be identified as such, independently of the vast array of processes and practices by which they are recognized as art. Although Dewey is not mentioned in this volume, one can easily acknowledge the author's clear indebtedness to the first pages of Art as Experience, where Dewey argues against taking the artistic objects displayed in museums as the standard for understanding works of art. Moreover, Cometti's answer was a clearly pragmatist one, insofar as he searched for the artistic factors contributing to the emergence of artworks from a broad web of material, social, and cultural relationships that are not properties of an independent and separated artworld, but part of a contingent form of life.

The positive counterpart to the criticism against autonomist pretensions about art is Dewey's thesis of a basic continuity between artistic practices and experience "in the raw" (3), which is to say experience as the series of interactions by which humans live and develop, dynamically becoming what they are by engaging with the environment they contribute to shape. All the above-mentioned pragmatist accounts of aesthetics share this idea in a variety of ways. It evidently lies at the core of everyday aesthetics, as stated in the previous section, as well as in various attempts to consider aesthetic features as characteristics and aspects inherent in the neurological, bodily, social, and environmental constrains of experience.

The conceptual framework of the continuity thesis is naturalism without reductionism (4), which characterizes - to different extents - most of the research trends under consideration. It takes the form of a rejection of dualism as a key category for understanding aesthetic aspects and phases both within experience and in the arts. In accordance with Dewey's criticism of the mind-body dualism, somaesthetics makes somatic experience and body consciousness the central focus of investigation as both a practical and a theoretical way out of the traditional dichotomy (Shusterman 2008). Mark Johnson's idea of the aesthetic as a primary feature of experience considers bodily perception as the first source of meaning, which in his view even grounds linguistic meanings (Johnson 2007). Mind-body and perception-language appear to be continuous, rather than opposed both ontologically and epistemologically, as is traditionally assumed. Enlightened neuroaesthetic approaches such as Jay Schulkin's one in this issue investigate how artful behaviours are connected to neurological resources developed by human organisms through their contingent but decisive development of cephalic capacities through changing circumstances. In the case of Berleant's environmental aesthetics and Alexander's eco-ontology, naturalism takes the form of a hard criticism of the modern conception of nature as ontologically different from subjective reason. Both scholars recover Dewey's choice to de-emphasize the subject in favour of a broadly biological stance focusing on human organisms as beings that constitute their lives through the interactions they have with their environment - which is constantly reshaped from the inside by both organic and sociocultural human actions. Our lives appear to be closely engaged with environmental circumstances, since humans are constitutively embedded in their environment. Environmental changes and disasters appear to be inextricably connected with human lives and destinies, given the clear mutual dependence between organic life and the environment. Consequently, environmental engagement becomes an aesthetic as well 
as ethical requirement, challenging both the paradigm of disinterested contemplation and the separation of aesthetic evaluations from moral norms and ethics.

This last, broadly political stance in environmental aesthetics leads us to one final family feature I wish to point out in this sketch. Most pragmatist aesthetics are, broadly speaking, of socio-political inspiration (5), although this can take very different forms, as we have briefly seen with reference to the aesthetics of the environment. Dewey's polemic against the so-called "museum conception" of art, its "compartimentalization," and the conception of artworks as "ethereal things" amounted to criticism of an elitist notion of art which deprived most people in highly industrialized urban contexts of the possibility of enjoying their job, their home, and ultimately their life. As stated by Mead (1926), the cultivation of the great masters of the past can be socially regressive if it contributes to strengthening social inequalities. Rick Tilman's original work can be credited for the recovery of Thornstein Veblen's inquiries into the structural relationships between the birth and development of social prestige and aesthetic behaviours - according to a view of "conspicuous consumption" and "invidious distinction" (Veblen 1899) that largely preceded Bourdieu's work on "symbolic capital" and "aesthetic distinction" (Bourdieu 1979). Tilman made Veblen's connections with Peirce, James, and Dewey clear, and supported the idea of an American tradition of social aesthetics, including Veblen, Dewey, and Charles Wright Mills - as readers will find in Thorntveit's paper in this issue. Perhaps, Howard Becker's work on the sociology of art might also be ascribed to this trend, given both his roots in Chicago Interactionism and his strong anti-elitist attitude, reflected in his view of artworks as webs of collaborative activities realized by different persons and through different contributions (Becker 1982). Shusterman's argument for blurring the boundaries between the fine arts and popular artistic practices and productions is based on a similar sensibility.

Melioristic stances supported by somaesthetics and by everyday aesthetics could be regarded as positive counterparts to the above-mentioned social criticism, insofar as they present themselves as opportunities to make individuals' lives better and more enjoyable. Without denying risks of aesthetization that are explicitly faced by both trends, cultivating a more conscious perception of one's own bodily limits and possibilities, as well as of ordinary practices and relationships, can have broadly political implications as it can reinforce pro-social attitudes, anti-consumerist behaviours, and anti-elitist stances.

29 As already stated, this is a provisional mapping, characterized by a certain degree of approximation in its proposal to consider the category of pragmatist aesthetics in the plural. It involves both the acknowledgement of an already existent complex web of reciprocal similarities, convergences, and differences, but also of an inevitable degree of arbitrariness, represented by the a posteriori invention of a category.

The field seems promising, especially when pragmatic insights are able to merge with current debates, as in the case of rising enactivist aesthetics - consider for example Shaun Gallagher's recent proposal concerning artistic performances (Gallagher forthcoming). Consider, too, applying a cultural naturalistic framework to cognitive sciences investigating artistic practices and aesthetic features within ordinary experience beyond the narrow limits of reductive neuro-aesthetics (Brown \& Dissanayake 2009). 
31 New issues are arising: for example, given that pragmatist aesthetics opposes the boundaries of the fine arts, high culture or great works of art in the standard sense, does it still have adequate tools to understand contemporary artistic productions and formal issues in twentieth-century arts? Another burning challenge regards the possible social contributions of an aesthetics of (ordinary) experience, given the complex economic conditionings characterizing everyday transactions in current postindustrial societies. I believe we should consider the arising of such difficulties not as a philosophical weakness within pragmatist aesthetics, but as a sign of its vitality, of its facing real issues and uncertainties, real "problems of men" (and women), rather than artificial doubts, in line with the best pragmatist tradition.

\section{BIBLIOGRAPHY}

ADORNO Theodor W. \& Max HORKHEIMER, (1947/2002), Dialectic of Enlightenment: Philosophical Fragments, Standford, Standford University Press.

ALEXANDER Thomas M., (1987), John Dewey's Theory of Art, Experience and Nature. The Horizons of Feeling. New York, SUNY Press.

ALEXANDER Thomas M., (2013), The Human Eros. Eco-ontology and the Aesthetics of Human Eros, New York, Fordham University Press.

ALeXAnder Thomas M., (2020), "Mythos and Polyphonic Pluralism," The Pluralist, 15 (1), 1-16.

ALLISON Raphael C., (2001), “Walt Whitman, William James, and Pragmatist Aesthetics,” Walt Whitman Quarterly Review, 20, 19-29. Online: (https://ir.uiowa.edu/wwqr/vol20/iss1/3/).

ANDERSON Douglas, (1984), "Peirce on Metaphor," Transactions of the Charles S. Peirce Society, 20 (4), 453-68.

ATKINS Richard Kenneth, (2008), “The Pleasures of Goodness: Peircean Aesthetics in Light of Kant's Critique of the Power of Judgment," Cognitio, 9 (1), 13-25.

BECKER Howard S., (1982), Art Worlds, Berkeley/Los Angeles/London, University of California Press. BERLEANT Arnold, (1992), The Aesthetics of Environment, Philadelphia, Temple University Press. BORDOGNA Francesca, (2001), “The Psychology and Physiology of Temperament: Pragmatism in Context," Journal of the History of the Behavioral Sciences, 37 (1), 3-25.

BOURDIEU Pierre, (1979), La distinction. Critique sociale du jugement, Paris, Les Éditions de Minuit. BOURDIEU Pierre, (1983), “The Field of Cultural Production," Poetics, 12, 311-56 BRADY Emily, (2003), Aesthetics of the Natural Environment, Tuscaloosa, The University of Alabama Press.

BROWN Steven \& Ellen DISSANAYAKE, (2009), "The Arts are more than Aesthetic: Neuroaesthetics as Narrow Aesthetics," in M. Skov \& O. Vartanian (eds), Foundations and frontiers in aesthetics. Neuroaesthetics, Amityville, NY, Baywood Publishing Co., 43-57. 
CALCATERRA Rosa Maria, (2019), Contingency and Normativity: The Challenges of Richard Rorty, Boston/ Leiden, Rodopi Brill.

CARLSON Allen, (2009), Nature and Landscape. An Introduction to Environmental Aesthetics, New York, Columbia University Press.

COMETTI Jean-Pierre, (2012), Art et facteurs d'art. Ontologies friables, Rennes, Presse Universitaires de Rennes.

COMETTI Jean-Pierre, (forthcoming), "De 'L'Art comme expérience' à 'L'Art à l'état vif'," in B. Formis \& M. Girel (eds), Pragmatisme et esthétique.

DANTO Arthur C., (1964), “The Artworld,” The Journal of Philosophy, 61 (19), 571-84.

DANTo Arthur C., (1992), "The Artworld Revisited: Comedies of Similarity," in Id., Beyond the Brillo Box. The Visual Art in Post-Historical Perspective, Berkeley/Los Angeles/London, California University Press, 3-53.

DELEUZE Gilles, (1986), Cinema 1. The Movement-Image, London, The Athlone Press.

DEWEY John, (1989), Art as Experience, vol. 10 of The Later Works, Carbondale and Edwardsville, Southern Illinois University Press.

DREON Roberta, (2019), "On a Certain Vagueness in the Definition of Art. Margolis' Aesthetics and Wittgenstein' Legacy," in L. Perissinotto \& D. Mantoan (eds), Paolozzi \& Wittgenstein. The Artist and the Philosopher, Basingstoke, Palgrave MacMillan, 160-77.

ECO Umberto, (1976), A Theory of Semiotics, Bloomington, Indiana University Press.

EHRAT Johannes, (2005), Cinema and Semiotic. Peirce and Film Aesthetics, Narration, and Representation, Toronto/Buffalo/London, University of Toronto Press.

FELDMAN Jessica R., (2002), "Positions of repose: the Victorian Modernism of William James," in Id., Victorian Modernism: Pragmatism and the Varieties of Aesthetic Experience, Cambridge, Cambridge University Press, 172-222.

GALlagher Shaun (forthcoming), Performance/Art: The Venetian Lectures, Milan, Mimesis International.

GILKS Mark, (2021), “Aesthetic Experience and the Unfathomable: A Pragmatist Critique of Hermeneutic Aesthetics,” The British Journal of Aesthetics, ayaa042. Online: (https://doi.org/ 10.1093/aesthj/ayaa042).

HAINIC Codruta, (2019), “Aesthetic Experience in the Semiotics of Charles S. Peirce," Agathos, 10 (2), 19-32.

HOCUTT Max Oliver, (1962), “The Logical Foundations of Peirce's Aesthetics," The Journal of Aesthetics and Art Criticism, 21 (2), 157-66.

HONNACKER Ana \& Magnus SCHLETTE (eds), (2020), Democracy as a Form of Life, European Journal of Pragmatism and American Philosophy, XII, 2. Online: (https://journals.openedition.org/ejpap/2063).

IBRI Ivo A., (2016), "Linking the Aesthetic and the Normative in Peirce's Pragmaticism: A Heuristic Sketch," Transactions of the Charles S. Peirce Society: A Quarterly Journal in American Philosophy, 52 (4), 598-610.

INNIS Robert E., (2014), “Dewey's Peircean Aesthetics," Cuadernos de Sistemática Peirceana, 6, 139-60. INNIS Robert E., (forthcoming), Dimensions of an Aesthetic Encounter: Essays in Analytical Linkages, New York, SUNY Press. 
JAMES William, (1975), Pragmatism, Cambridge, Mass., Harvard University Press.

JOHNSON Mark, (2007), The Meaning of the Body. Aesthetics of Human Understanding, Chicago/London, Chicago University Press.

LEFEBVRE Martin, (2007), “Peirce's Esthetics: A Taste for Signs in Art," Transactions of the Charles S. Peirce Society: A Quarterly Journal in American Philosophy, 319-44.

LEVIN Jonathan, (1994), “The Esthetics of Pragmatism,” American Literary History, 6 (4), 658-83.

MADDALENA Giovanni, (2014), “'Non far violenza a nessuna parte dell'anima umana'. Peirce, l'estetica e la sintesi," Cuadernos de Sistemática Peirceana, 6, 103-17.

MARGoLIS Joseph, (1974), "Works of Art as Physically Embodied and Culturally Emergent Entities," The British Journal of Aesthetics, 3 (14), 187-96.

MARGolis Joseph, (2009), The Arts and the Definition of the Human. Toward a Philosophical Anthropology, Stanford, Stanford University Press.

MARGOLIS Joseph, (2015), "Towards a Metaphysics of Culture," in D. M. Grube \& R. Sinclair (eds), Pragmatism, Metaphysics and Culture. Reflections on the Philosophy of Joseph Margolis, Helsinki, Nordic Pragmatism Network, 1-35.

MARGolis Joseph, (2017), Three Paradoxes of Personhood: The Venetian Lectures, Milan, Mimesis International.

MATTEUCCI Giovanni, (2019), Estetica e natura umana. La mente estesa tra percezione, emozione ed espressione, Roma, Carocci.

MEAD George Herbert, (1926), “The Nature of Aesthetic Experience," International Journal of Ethics, $36,382-92$.

Nö̈ Alva, (2015), Strange Tools. Art and Human Nature, New York, Hill and Wang.

PARRET Herman (ed.), (1994), Peirce and Value Theory. On Peircean Ethics and Aesthetics, Amsterdam, John Benjamins Publishing Company.

SAITO Yuriko, (2021), “Aesthetics of the Everyday," in E. N. Zalta (ed.), The Stanford Encyclopedia of Philosophy. Online: (https://plato.stanford.edu/entries/aesthetics-of-everyday/).

SANTAElla Lucia, (2001), “Esthetics, the Supreme Ideal of Human Life," Semiotica, 135, 175-89.

SHERIFF John K., (1989), The Fate of Meaning. Charles Peirce, Structuralism, and Literature, Princeton, Princeton University Press.

SHUSTERMAN Richard, (1992), Pragmatist Aesthetics: Living Beauty, Rethinking Art, Oxford, Blackwell. SHUSTERMAN Richard, (2008), Body Consciousness. A Philosophy of Mindfulness and Somaesthetics, Cambridge, Cambridge University Press.

SHUSTERMAN Richard, (2011a), "Soma, Self, and Society: Somaesthetics as Pragmatist Meliorism," Metaphilosophy, 42 (3), 314-27.

SHUSTERMAN Richard, (2011b), “The Pragmatist Aesthetics of William James," British Journal of Aesthetics, 51 (4), 347-61.

SHUSTERMAN Richard, (2012), "Pragmatism's Embodied Philosophy: From Immediate Experience to Somaesthetics," in Routledge Handbook of the Body, edited by B. Turner, London and New York, Routledge, 34-48. 
SHUSTERMAN Richard, (2014), “The Invention of Pragmatist Aesthetics: Genealogical Reflections on a Notion and a Name," in W. Małecki (ed.), Practicing Pragmatist Aesthetics. Critical Perspectives on the Arts, Leiden, Brill, 11-32.

SHUSTERMAN Richard, (2019), "Rorty's Aesthetics," Archives de philosophie, 3 (82), 557-72.

SMiTH C. M., (1972), “The Aesthetics of Charles S. Peirce,” The Journal of Aesthetics and Art Criticism, $31(1), 21-9$.

TILMAN Rick, (2004), Thorstein Veblen, John Dewey, C. Wright Mills, and the Generic Ends of Life, Lanham, Rowman and Littlefield.

TRIGONI Thalia, (2015), "Corporeal Cognition: Pragmatist Aesthetics in William James," in

A. Scarinzi (ed.), Aesthetics and the Embodied Mind: Beyond Art Theory and the Cartesian Mind-Body

Dichotomy, Dordrecht, Netherlands, Springer, Contributions to Phenomenology, vol. 73, 55-69.

VEBLEN Thorstein, (1899), The Theory of the Leisure Class. An Economic Study in the Evolution of Institution, New York, The Modern Library.

viola Tullio, (2012), "Peirce and Iconology. Habitus, Embodiment, and the Analogy between Philosophy and Architecture," European Journal of Pragmatism and American Philosophy, IV (1). Online: (https://journals.openedition.org/ejpap/764).

WESTBROOK Robert B., (1991), John Dewey and American Democracy, Ithaca, NY, Cornell University Press.

\section{NOTES}

1. See note 3.

2. Cf. Alexander 2020 for a different view. On Shusterman Pragmatist Aesthetics fortune see the "Symposium on R. Shusterman, Pragmatist Aesthetics 20 years later" in this journal, 2012, 1, IV. Online: (https://journals.openedition.org/ejpap/758).

3. There is an already rich literature on Peirce from a broadly aesthetic point of view. On Peirce's aesthetics in general, see Hocutt 1962, Smith 1972, Parret 1994, Santaella 2001, Lefebvre 2007, Atkins 2008, Maddalena 2014, Innis 2014, Ibri 2016, Hainic 2019, and Innis forthcoming. On specific aesthetic topics, see Anderson 1984, Sheriff 1989, Ehrat 2005, and Viola 2012. Eco 1976 and Deleuze 1986 should be mentioned as the most influential cases of the adoption of Peirce's insights within the field of aesthetics. I am personally grateful to Tullio Viola for his valuable help in compiling a provisional list of references on this issue.

James' contribution to the aesthetic field has received less attention. On James' "pragmatist aesthetics," see Shusterman $(2012,2011 \mathrm{a}, 2011 \mathrm{~b})$ and Trigoni 2015. On James' aesthetic understanding of cognition, see Johnson 2007. Other contributions on specific issues are Levin 1994, Allison 2001, Gilks 2021, and Feldman 2002. Another line of research is that proposed by Bordogna 2001. In her analysis of Jamesian psychology and physiology of temperament, Bordogna reconstructs the "physiological aesthetics" of the late nineteenth century by arguing that "James followed with interest developments and publications in physiological esthetics, which he regarded as incomparably preferable to philosophical esthetics" (Bordogna 2001: 19). I am indebted to Michela Bella for her precious help in collecting this list of inquires into James's contribution from an aesthetic point of view.

4. Rorty's position and insights too would deserve further exploration. On this issue see Calcaterra (2019: 69) and Shusterman 2019. 


\section{ABSTRACTS}

This paper aims to map and highlight the diverse heritage of Pragmatism in aesthetics. It argues that pragmatist aesthetics represents an interesting third way of doing aesthetics beyond the analytic philosophy of art and continental aesthetics. It offers a first, provisional sketch of existing research trends in pragmatist aesthetics, such as somaesthetics, environmental aesthetics, everyday aesthetics, and social aesthetics. Furthermore, it identifies some "family resemblances" connecting most pragmatist "relatives" in the field of aesthetics: the idea that (1) aesthetics is broader than the traditional philosophy of art, (2) the criticism of the view of art as constituting an independent realm or an autonomous system, (3) the thesis of a basic continuity between artistic practices and experience "in the raw," (4) the adoption of a naturalistic yet nonreductive stance, and (5) a broadly socio-political inspiration.

\section{AUTHOR}

\section{ROBERTA DREON}

Ca' Foscari University, Venice

robdre[at]unive.it 